\title{
PENGALAMAN KELUARGA MENJAGA ANAK YATIM AIDS: KAJIAN KES DI PERKAMPUNGAN NELAYAN, PERLIS MALAYSIA
}

\section{Ezarina Zakaria, PhD}

Pensyarah Kanan, Pusat Pengajian Psikologi dan Pembangunan

Manusia, Fakulti Sains Sosial dan Kemanusiaan, Universiti

Kebangsaan Malaysia.ezaz@ukm.my

\section{Haris Abd. Wahab, PhD}

Pensyarah Kanan, Jabatan Pentadbiran dan Keadilan Sosial, Universiti Malaya.haris@um.edu.my

This study is an attempt to explore experiences of families who switch parenting roles to AIDS Orphans, where either both or either of their parents was deceased due to AIDS. According to the United Nations, a child is considered as AIDS Orphans irrespective of whether he or she is infected with HIV from their parents or is free from the infection. This qualitative study was conducted in a fishing village in Perlis, Malaysia. Five families from a list of HIV/AIDS patients provided by the Ministry of Health were selected using purposive sampling method. Five primary guardians, consisting of mothers and grandmothers of the AIDS Orphans were interviewed in-depth. The study demonstrates that switching parenting to AIDS Orphans is physically and mentally challenging due to factors such as increasing demand of family roles and tasks, financial constraints, ways in which the children perceive and accept their status as AIDS Orphans, the bleak future of the children, and the unpleasant ways the children were treated and stigmatised by the community.

Kata kunci: Kerja sosial keluarga, anak yatim AIDS, komuniti nelayan. 


\section{PENDAHULUAN}

HIV/AIDS memberi impak negatif ke atas perkembangan sesebuah keluarga. Pengesahan status seropositif mendesak keluarga untuk berhadapan bukan sahaja dengan isu jangkitan yang membawa kematian tetapi juga stigma masyarakat (Antle, DeMatteo, Goldie, King \& Wells, 2001; Anderson, 2001). Sejurus status HIV/AIDS ahlinya disedari, keupayaan keluarga untuk memperolehi sokongan sosial menjadi terbatas sedikit demi sedikit. Kesannya, keluarga merasa takut serta mula menyisihkan diri sehingga emosi mereka menjadi lebih tertekan. Isu-isu yang berkaitan dengan

penyisihan akibat stigma dan diskriminasi HIV/AIDS inilah yang mendorong lebih ramai pihak untuk terus hidup dalam penafian.

Sehingga akhir tahun 2010, UNAIDS (2011) menganggarkan 34 juta penduduk dunia hidup dengan HIV/AIDS dan lebih 95 peratus daripada jumlah keseluruhan ini tinggal di negara-negara membangun. Anggaran daripada jumlah besar ini, 31 juta adalah penduduk dewasa dengan 15.7 juta orang daripadanya adalah wanita dan 2.5 juta lagi adalah kanak-kanak di bawah umur 15 tahun. Sepanjang tahun 2010 juga, AIDS menjadi punca kematian bagi 1.8 juta penduduk dunia; termasuklah 0.3 juta kanak-kanak di bawah umur 15 tahun. Sehingga kini sebanyak 390, 000 kes baru jangkitan HIV telah dikenalpasti dalam kalangan kanak-kanak di seluruh dunia (UNAIDS, 2011).

Kematian pengidap HIV tidak pernah menjadi petunjuk berkurangnya impak HIV/AIDS. Malah kematian itu sendiri menjadi permulaan kepada impak psikososial yang lebih besar apabila fenomena yatim AIDS terwujud yang sehingga kini terus meningkat. Memandangkan pengidap HIV/AIDS terdiri daripada individu dalam lingkungan umur produktif dan merupakan ketua keluarga, kematian mereka pastinya meninggalkan anak-anak yang menjadi yatim dan terbiar. Yatim AIDS didefinisikan oleh United Nations sebagai kanak-kanak yang kematian salah seorang atau kedua-dua ibubapa kerana HIV/AIDS. Yatim AIDS bukan hanya terhad kepada kanak-kanak yang mewarisi HIV daripada ibubapa tetapi juga meliputi kumpulan yang tidak dijangkiti tetapi dikategorikan yatim AIDS kerana kematian ibubapa kerana HIV/AIDS (UNAIDS, 2010). Ini dapat dilihat di Afrika, antara negara dunia yang mempunyai statistik jangkitan HIV/AIDS yang paling tinggi. 
AIDS bertanggungjawab mewujudkan fenomena peningkatan bilangan kanak-kanak di Afrika tanpa ibubapa. Statistik dunia menunjukkan lebih daripada 16 juta kanak-kanak di bawah umur 18 tahun telah menjadi anak yatim kerana AIDS. 14.8 juta daripada jumlah kanak-kanak tersebut tinggal di Sub-Saharan Afrika (UNAIDS, 2010). Umur yatim AIDS di Afrika adalah dalam lingkungan 0 hingga 4 tahun (15 peratus), 5 hingga 9 tahun (35 peratus) dan 10 hingga 14 tahun (50 peratus). Negara-negara seperti Zimbabwe, Bostwana dan Swaziland yang terjejas teruk kerana AIDS mempunyai peratusan bilangan yatim AIDS yang besar. Kes kanakkanak yang menjadi anak yatim kerana ibubapa meninggal dunia akibat HIV/AIDS mencatatkan 12 peratus hingga 16 peratus daripada jumlah keseluruhan anak yatim di negara-negara tersebut. Menurut UNAIDS (2008), bilangan yatim AIDS dijangka akan kekal tinggi menjelang tahun 2015 meskipun berlaku perluasan akses kepada rawatan antiretroviral dalam komuniti.

Skala krisis yatim AIDS dan statistik sebenar kes dikaburi oleh sela masa antara ibubapa mengetahui status HIV dengan masa ibubapa meninggal dunia kerana AIDS. Selagi kes dewasa meninggal dunia kerana AIDS mengalami peningkatan berterusan sehingga abad akan datang, selagi itulah bilangan yatim AIDS akan meningkat. Unjuran ini memberi dua makna pertambahan utama. Pertama, bertambahnya bilangan anak-anak yatim yang kehilangan ibubapa kerana HIV/AIDS. Kedua, yatim AIDS ini terpaksa pula meneruskan hidup kurang penjagaan dan kasih sayang akibat stigma serta diskriminasi yang selama ini mengepung persekitaran mereka tidak kira samada mereka turut dijangkiti HIV ataupun tidak.

Setelah kematian ibubapa, kanak-kanak ini selalunya dipelihara oleh keluarga kembangan atau saudara mara mereka sendiri. Datuk dan nenek menjadi pilihan utama dalam kebanyakkan kes pengambilalihan penjagaan yatim AIDS. Anak-anak ini biasanya tinggal di dalam keluarga besar yang diketuai oleh wanita sebagai pencari nafkah utama (Monasch \& Boerma, 2004). Lazimnya ahli keluarga yang ramai terpaksa bergantung kepada pencari nafkah tunggal untuk memenuhi semua keperluan. Meskipun keluarga kembangan mengambil alih penjagaan, perbincangan mengenai pengalaman penjagaan khusus untuk yatim AIDS masih samar. Apa yang dialami oleh keluarga setelah pesakit HIV/AIDS meninggal dunia dengan anak-anak yang hilang tempat bergantung masih perlu penelitian.

Artikel ini bertujuan membentangkan secara khusus hasil kajian impak psikososial HIV/AIDS ke atas keluarga pesakit yang telah dijalankan di sebuah perkampungan nelayan di Kuala Perlis, Perlis. Artikel memberi 
tumpuan kepada salah satu penemuan dari kajian iaitu pengalaman keluarga menjaga yatim AIDS.

\section{METODOLOGI KAJIAN}

Kajian ini bertujuan untuk mengenalpasti pengalaman keluarga mengambil alih peranan penjagaan anak yatim AIDS setelah kematian ibu atau bapa mereka. Kajian ini merupakan kajian eksploritariyang menggunakan pendekatan kualitatif. Kajian memerlukan keluarga mendedahkan pengalaman sebenar berhubung perubahan yang terpaksa dilalui oleh mereka setelah kematian pesakit. Pengalaman dan cerita sebenar yang diperolehi menerusi temubual bersemuka adalah sumber data utama bagi kajian ini. Skop temubual dibentuk menerusi analisa dapatan kajian terdahulu berkenaan impak psikososial HIV/AIDS ke atas pesakit dan juga keluarga. Pengumpulan data dijalankan di kediaman responden. Data dianalisa secara induktif bersesuaian kaedah kualitatif dengan mengenalpasti tema utama yang timbul. Analisa perbandingan dibuat bagi mengenal pasti perbezaan serta persamaan antara tema.

Setiap keluarga yang telah dikenalpasti terdiri daripada keluarga pesakit HIV/AIDS yang telah dirujuk ke Unit AIDS/STD Hospital Kangar, Perlis. Hanya senarai nama yang keluarkan oleh pihak Kementerian Kesihatan Malaysia sahaja termasuk dalam penapisan dan pemilihan sebagai responden kajian. Pemilihan secara terhad ini didorong oleh keakuran pengkaji kepada menjaga kerahsiaan keluarga. Pemilihan responden juga tertakluk kepada persetujuan keluarga untuk menyertai kajian ini. Usaha kajian untuk mendapatkan maklumat tanpa menimbulkan stigma dan diskriminasi telah membentuk batasan bagi memilih responden yang lebih ramai.

\section{PENEMUAN DAN PERBINCANGAN KAJIAN}

\section{Maklumat Responden}

Sebanyak lima buah keluarga dari kumpulan etnik Melayu telah bersetuju melibatkan diri di dalam kajian ini. Keluarga yang dipilih merupakan keluarga nelayan dan ahli keluarga mereka yang telah meninggal dunia kerana HIV/AIDS; bekerja sebagai nelayan semasa masih hidup. Kesemua pesakit di dalam keluarga ini telah meninggal dunia sebelum pengumpulan data dilakukan. Dua daripada lima keluarga ini merupakan keluarga asas 
yang terdiri daripada isteri pesakit dan anak-anak sahaja. Manakala tiga keluarga lagi adalah keluarga luas dengan bilangan ahli yang lebih ramai dan penjagaan yatim AIDS melibatkan penjaga yang lebih dari seorang. Empat orang penjaga daripada lima buah keluarga memberitahu pengkaji bahawa ahli keluarga mereka adalah pengguna dadah dan telah dijangkiti HIV kerana berkongsi jarum suntikan. Manakala sebuah keluarga lagi memaklumkan ahlinya dijangkiti menerusi aktiviti heteroseksual. Maklumat ini telah disahkan oleh pengkaji dengan merujuk kepada Pegawai Perubatan Hospital Kangar, Perlis.

Seramai lima orang penjaga utama telah ditemubual secara bersemuka. Pemilihan penjaga ini sebagai responden kajian telah dibuat secara bertujuan. Mereka terdiri daripada ibu, kakak atau isteri kepada pesakit. Kesemua informan/responden adalah wanita dan berumur dalam lingkungan 28 tahun hingga 63 tahun. Responden memberi penjagaan sepenuhnya semasa pesakit terlantar sehinggalah pesakit meninggal dunia. Mereka juga kini mengambil alih peranan penjagaan anak-anak pesakit. Bagi maksud artikel ini, anak-anak pesakit di dalam kajian akan disebut sebagai Yatim AIDS sebagaimana menurut UNAIDS (2010).

\section{Pertambahan peranan keluarga}

Kesemua responden yang ditemubual mengakui berhadapan dengan pertambahan peranan apabila mengambil alih sepenuhnya penjagaan anakanak pesakit setelah kematian bapa mereka. Tambahan pula, kajian mendapati ada ibu kepada yatim AIDS ini yang bertindak meninggalkan anak-anaknya yang masih kecil dan bersekolah kepada adik-beradik suami. Keluarga ini berhadapan dengan dilema antara tanggungjawab penjagaan dengan ketidakupayaan material akibat mengambil alih peranan ini. Katanya semasa ditemubual:

"Mana saya nak kena kelola rumah lagi, mana saya nak kelola anak-anak dia..had kecik-kecik tu, saya pun ada anak-anak, tak boleh tinggal..suami saya lagi. Semua dok buang kat saya, sampai saya marah kat mak dia. Dia bercerai dengan adik saya, kahwin lain tapi lepaih anak kat kita. Memanglah aruah suruh jaga anak dia kan tapi tolonglah sama. Saya maki dia..emm..hang dapat tau laki hang lagu tu (dijangkiti HIV), hang lepaih kat kami. Aku yang nak kena pi basuh ayaq kencing depa semua. Kita ni 
pun bercakaplah jugak kan, bukan tak sayang kat anak dia...emm..entahlah, tak tau nak habaq.."

Pertambahan peranan keluarga turut meliputi keperluan menanggung persekolahan yatim AIDS. Keupayaan pendapatan bulanan yang rendah bagi setiap keluarga menjadi faktor pendorong utama masalah ini. Ketidakupayaan lebih ketara dikenalpasti wujud dalam keluarga asas yang bergantung sepenuhnya kepada pesakit untuk saraan sebelum ini. Bagi kes keluarga asas, isteri biasanya perlu menjadi penyara tunggal selepas kematian pesakit. Dua keluarga asas yang menyertai kajian ini melaporkan berhadapan masalah untuk mencari pekerjaan bagi menyara keluarga. Isteri pesakit merasa bimbang dan tidak yakin untuk bekerja. Kebimbangan ini diakui oleh isteri berpunca daripada kurangnya pendedahan kepada persekitaran luar dan pekerjaan sebelum ini. Kebiasaannya kesemua urusan luar dan tanggungjawab saraan keluarga terletak sepenuhnya kepada suami. Pasangan merasa bimbang tidak diterima untuk bekerja kerana kerap ditanya tentang status HIV/AIDS apabila status suaminya diketahui oleh majikan.

"kak rasa tak berapa nak bolehlah..rasa macam tak berapa
faham sangat nak pi mintak kerja..dah selama ini pun dia
yang dok tanggung kami semua..bila kak nak kena pi
kerja..kak tak berapa ..perasan macam tak berapa nak
yakinlah..nak buat apa pun rasa macam tak tau..kak takut
sat lagi depa tau suami kak sakit apa..depa tak mau kat kita
ke..sat lagi kita pulak berasa hati. Tapi kalau tak pi carik
kerja nak makan apa...budak-budak sekolah
lagi..sementara depa nakbesaq"

Keperluan peranan menjaga dan menyara menjadi lebih menekan apabila datuk atau nenek yang semakin tua menjaga mereka tanpa bantuan saudara mara yang lain. Seorang responden iaitu ibu pesakit merasakan keadaan beliau yang semakin tua dan uzur menyukarkan beliau meneruskan peranan menyara cucunya yang masih kecil. Keadaan kewangan keluarga adalah tidak stabil. Keluarga asalnya bergantung sepenuhnya kepada pesakit yang bekerja sebagai nelayan untuk menyara mereka.

“...nak harap makcik sorang, tak lalu (larat) lah. Mana nak pi carik duit, kita pun bukan senang.Nak makan pun dok pikiaq. Dia pesan kat makcik nak anak dia sekolah sini, budak-budak ni pun seronoklah..ya lah dapat sekolah. Tapi 
kena buang sетиa (berharap semua) kat kita lah, makcik mana nak tau hidup lama mana. Ada orang upah suruh buat apa-apa kerja, adalah. Kalau takdak, dok saja la. Nasib baik juga dok gagah welfare (bantuan kebajikan) tiap bulan"

Hasil kajian mendapati anak-anak yang ditinggalkan oleh pesakit masih bergantung kepada keluarga. Semakin kecil anak-anak ini, maka semakin besarlah pergantungan mereka. Analisa literatur menunjukkan sememangnya penjagaan yatim AIDS selepas kematian ibu bapa dipikul oleh keluarga luas. Mereka dipelihara oleh datuk, nenek dan saudara mara terdekat sehingga dewasa (UNAIDS, 2010, 2008; Ankrah, 1994; Onyango dan Waiji, 1988). Impak kematian ibu atau bapa kerana AIDS lebih dirasai oleh yatim AIDS apabila dipengaruhi persekitaran luar antaranya kedudukan ekonomi isirumah (UNICEF, 2006). Yatim AIDS berhadapan risiko keciciran sekolah, kurang nutrisi pemakanan, pengabaian penjagaan kesihatan, hak menerima perlindungan serta keselamatan rentetan dari ketidakcukupan ekonomi penjaga mereka yang baru (Monasch \& Boerma, 2004). Keperluan kewangan mula berubah sejak dari awal yatim AIDS dipelihara sehinggalah mereka dewasa. Keperluan ini perlu dikenalpasti secara berterusan agar dapat memenuhi peringkat-peringkat keperluan ahli keluarga yang berbezabeza.

Keluarga perlu membuat perancangan untuk meneruskan kefungsian sosial. Langkah awal boleh diambil dengan memberikan maklumat atau saluran yang sesuai untuk membantu keluarga membuat perancangan awal tentang masa hadapan yatim AIDS. Langkah ini boleh bermula sebelum ibu bapa mereka meninggal dunia lagi. Perancangan melibatkan penjagaan, sumber kewangan dan saraan persekolahan dengan mengutilisasikan sepenuhnya sumber dalaman keluarga boleh diberi perhatian dan diusahakan secara bersama. Perhatian juga seharusnya diberikan kepada sumber-sumber luar yang dipunyai oleh keluarga samada daripada saudara mara, jiran tetangga ataupun sumber sokongan sosial formal dalam membantu mengurangkan bebanan menyara yatim AIDS. Para profesional di dalam bidang kesihatan dan perkhidmatan manusia seperti Pegawai Perubatan dan Pekerja Sosial boleh memainkan peranan membantu keluarga melakukan persediaan untuk meneruskan kehidupan selepas kematian pesakit. 
Walau bagaimanapun, kepekaan dan usaha aktif keluarga ini perlulah terlebih dahulu mengambil kira sejauhmana keluarga bersedia mendedahkan status seropositif dan melibatkan pihak lain dalam perancangan mereka (Ezarina, 2008). Ini kerana reaksi serta penerimaan umum khususnya dalam komuniti nelayan seperti di dalam kajian ini masih kuat dibentuk oleh stigma dan diskriminasi HIV/AIDS. Ketakutan untuk berterus terangdan bersifat terbuka dalam mencari bantuan sokongan sosial berupaya merencatkan perancangan masa hadapan sesebuah keluarga yang ahlinya dijangkiti HIV.

\section{Reaksi dan penerimaan Yatim AIDS tentang kematian}

Pengalaman menjaga yatim AIDS turut mendedahkan keluarga dengan perasaan takut serta bimbang tentang penerimaan anak-anak ini terhadap kematian. Ketakutan ini termasuklah bagaimana untuk menghadapi pertanyaan tentang punca kematian. Tambahan pula keluarga menceritakan anak-anak pesakit sering bertanya tentang punca penyakit dan kematian bapa mereka. Seperti mana yang dinyatakan oleh seorang responden semasa menceritakan perbualan beliau dengan anak saudara yang dijaganya:

\section{"Dia ada tanya kat kak, ayah dia sakit apa? Sakit HIV ka? Kak tanya dia apa dia tau pasal sakit tu. Dia jawab kat kak, dia dengaq-dengaq sakit tu takdak boleh ubat, tu pasal ayah dia mati"}

Kebimbangan-kebimbangan ini timbul selaras dengan ketakutan keluarga terhadap 'label' yatim AIDS yang berupaya memberi tekanan emosi sehingga kanak-kanak ini dewasa kelak. Tanpa penjelasan dan pujukan yang wajar, kanak-kanak mungkin tidak faham mengapa sesuatu perubahan dan kehilangan kerana kematian akan berlaku di dalam kehidupan mereka. Keluarga menganggap penjelasan yang wajar juga perlu bagi mengelakkan terjadinya situasi kanak-kanak tadi mengalami tekanan perasaan akibat diberitahu tentang status jangkitan keluarganya daripada sumber yang tidak betul. Menurut responden:

"kak risau jugak kan kalau tak boleh nak habaq semua..emm..yalah dah dia kecik lagi, kita habaq sikit pun jadilah. Takut nanti dia pi (pergi) tanya rata-rata, orang lain bagitau tak betui ka, dok cakap tak ketahuan (tak betul) bagi dia sedih ka kan..emm..yalah mana nak tau hati 
orang lain, depa tak boleh nak lepaih (lepas/luah) kat kita ...emm..depa (mereka) pi lepaih (lepas/luah) cakap kat dia. Budak-budak ni pun ada perasaan jugak. Memanglah depa kecik lagi. Dahlah pak (bapa) depa dah mati, sat lagi depa rasa lagu lain sikit, kita nanti nak susah sama..tu yang kak bagitau jugak..kut esok dia pelan (makin) besaq (besar) dia fahamlah kan. Tapi tengok sekarang ni pun macam dah bolehlah sikit-sikit kut, orang kata boleh nak terima lah kut..."

Penjelasan secara wajar juga dirasakan membantu dan memudahkan penerimaan kanak-kanak terhadap situasi jangkitan di dalam keluarga mereka.

Di samping itu, ketakutan keluarga di dalam kajian ini dikenal pasti turut terbentuk melalui anggapan dan persepsi mereka sendiri tentang reaksi orang lain terhadap yatim AIDS di bawah jagaan mereka. Persepsi akan distigma dan didiskriminasikan pada satu-satu masa adalah lebih kuat dirasai daripada stigma dan diskriminasi yang benar-benar berlaku (Bharat, 1999).

Bagi ahli keluarga yang dewasa, kematian bukan sahaja memerlukan mereka bertindak menguruskan tekanan emosi akibat kehilangan tetapi juga perlu membuat keputusan praktikal tentang anak-anak yang ditinggalkan pesakit. AIDS turut membawa makna kanak-kanak yang masih kecil perlu berhadapan dengan kematian ahli dewasa yang paling rapat dengan mereka seperti ibu, bapa atau kedua-duanya. Walaupun kanakkanak ini masih kecil dan berkemungkinan tidak benar-benar memahami mengapa kematian ibu bapa berlaku awal, tetapi kanak-kanak ini boleh merasai kehilangan orang yang penting dalam hidup mereka (Nugroho, 2012; Subbarao dan Coury, 2004). Kecenderungan ini boleh menyebabkan mereka mengalami tekanan emosi atau perubahan personaliti seperti menjadi murung dan pendiam. Keluarga ini perlu dibekalkan dengan sokongan sosial agar tidak merasa bimbang dengan isu stigma. Bantuan sokongan berupa maklumat yang tepat dan sokongan emosi dari semasa ke semasa adalah perlu bagi membantu keluarga meneruskan kehidupan normal.

\section{Pengalaman keluarga berhadapan reaksi dan penerimaan komuniti}

HIV/AIDS adalah kondisi kesihatan yang diberi label negatif. Bermula dari pendedahan status pengidapnya, beralih kepada kematian dan sehinggalah kepada penerusan hidup yatim AIDS sehingga dewasa, penyakit ini masih kekal distigmakan. Keluarga di dalam kajian ini mendedahkan pengalaman 
mereka berhadapan dengan reaksi negatif ahli komuniti khususnya ke atas pasangan serta anak-anak pesakit. Yatim AIDS di dalam kajian ini distigmakan sehingga mereka dirasakan sukar memperolehi penerimaan komuniti. Salah seorang responden memberitahu:

"kak nampak depa katup (tutup) pintu kalau anak kak pi
(pergi) nak main-main, kira nak pi (pergi) berkawan
dengan anak-anak depa lah, kalau anak depa main kat luaq
(luar), anak kak mai (datang) nak campuq (campur) sama
(bermain bersama-sama), sat lagi depa panggil anak depa
masuk rumah. Kak intai daripada tingkap, kak nampaklah.
Kita berasa sedih sangatlah kan, awat (kenapa) depa
tergamak buat kat budak-budak? Padahal depa (anak-
anak) bukan nakfaham apa.."

Isteri dan anak-anak pesakit juga kerap ditanya oleh jiran tetangga tentang status mereka sendiri. Reaksi umum yang sering ditunjukkan adalah pertanyaan samada keluarga bebas daripada jangkitan HIV atau tidak. Perubahan fizikal dan kesihatan akan menjadi perkara utama yang diutarakan oleh komuniti. Pasangan sering ditanya mengapa fizikalnya semakin kurus dan cengkung selepas kematian suaminya. Begitu juga dengan sebarang perubahan kepada kesihatan anak-anak akan segera menjadi perhatian jiran tetangga dan saudara mara. Mereka sering bertanya samada isteri pesakit telah menjalani ujian HIV atau tidak. Walaupun telah dinyatakan bebas daripada jangkitan HIV, beliau akan tetap ditanya tentang kekerapan atau sudah berapa kali ujian dilakukan bagi mengetahui pengesahannya. Menurut keluarga, mereka tidak mendapat kepercayaan daripada persekitaran apabila status mereka terus dicurigai. Jiran dan saudara mara turut menggesa isteri pesakit membawa kesemua anaknya untuk pemeriksaan bagi mendapat pengesahan bahawa mereka juga bebas daripada jangkitan HIV/AIDS.

"setiap kali jumpa kak, mesti depa tanyalah..awat (kenapa) badan hang makin kurus, hang tak sihat ka? Depa selalu tanya lah kat kak, pantang depa jumpa mesti tanya. Kalau jumpa kat mana-mana, kat pasar malam ka depa terserempak tu depa tegur lah, habis semua dengan anakanak kak ni depa tanya, kami dah pi check ke belum? kalau had yang kecik ni selsema ka, budak-budak biasalah kan, demam $k a$, nanti..emm..depa tanyalah lagi. Depa 
sebenarnya nak tanya pasal sakit tu, tapi depa tak tanya terus tau, depa pusing kut lain dulu..kita pun fahamlah, dah kerap sangat."

Reaksi masyarakat dirasakan oleh keluarga seolah-olah begitu yakin bahawa keluarga terutamanya isteri turut dijangkiti HIV ataupun tidak akan terlepas dari turut dijangkiti selepas beberapa tahun kelak.

Anak-anak pesakit juga dibebani dengan pertanyaan berulangkali tentang penyakit bapa mereka. Pertanyaan sering dibuat kepada anak-anak ini tanpa pengetahuan ibu mereka. Isteri pesakit hanya menyedari tentang reaksi ini setelah diceritakan oleh anak-anak beliau kemudiannya:

\begin{abstract}
"kadang-kadang depa tanya budak-budak, depa tanyalah ayah hang sakit apa? Sakit AIDS ka?..kak tak tau, budakbudak balik depa cerita lah kat kak. Depa habaq (beritahu) sapa-sapa (siapa) tanya depa, kak tau sapa yang selalu dok tanya. Depan kita depa tak tanya, tapi depa tanya budakbudak. Tu yang kak berasa macam tak seronok tu. Bukan apa, kesian kat depa ni..depa kecik lagi.."
\end{abstract}

HIV/AIDS adalah jangkitan yang distigmakan, menjejaskan kondisi kesihatan, boleh berjangkit dan membawa maut. Implikasi ini menyebabkan keluarga berada dalam ketakutan kerana distigmakan sedangkan keperluan untuk penjagaan, mendapatkan sokongan sosial dan diterima seperti orang lain adalah cukup tinggi. Rasa takut dipulaukan kerana stigma dan diskriminasi menyebabkan keluarga mempunyai pengalaman berhadapan impak psikososial HIV/AIDS secara bersendirian (Bharat, 1999).

Stigma HIV/AIDS juga telah menyebabkan status pasangan dan anak-anak pesakit sering dicurigai oleh masyarakat. Reaksi asas yang sering ditunjukkan selalunya berupa pertanyaan berulangkali untuk mengesahkan status. Label serta stigma seterusnya menimbulkan respon awam ke arah menyisih dan menafikan kepentingan pihak yang distigmakan. Di dalam kajian ini terdapat dua buah keluarga yang melaporkan jiran tetangga menghalang anak mereka bermain dengan anak-anak pesakit. Keadaan ini secara tidak langsung menunjukkan yatim AIDS bukan sahaja perlu memahami kesan kehilangan tetapi juga terpaksa memahami mengapa sesetengah ibu bapa rakan-rakan mereka tidak membenarkan mereka berkawan dan bergaul bersama-sama atau mengapa terdapatnya sesetengah saudara mara dan penduduk kampung memulaukan mereka. Tanpa penjelasan yang diberikan secara wajar dan bersesuaian dengan umur atau 
peringkat perkembangan kanak-kanak ini, adalah sukar untuk mereka memahami mengapa sesuatu peristiwa yang berlaku perlu mengubah kehidupan rutin mereka.

Pandangan keluarga bahawa anak-anak yang masih kecil tidak memerlukan penjelasan lanjut kerana mereka mungkin tidak dapat memahami sesuatu peristiwa atau tragedi di dalam keluarga perlulah dikikis. Ini penting kerana impak psikososial HIV/AIDS dirasai oleh semua ahli keluarga termasuklah kanak-kanak. Sepatutnya kepentingan kanak-kanak turut diberi perhatian serius oleh keluarga sepertimana kepentingan penjaga atau ahli dewasa yang lain. Bagi ahli keluarga dewasa yang menjaga yatim AIDS pula, perlu diberi sokongan sosial bukan sahaja dalam membantu mereka berdaya tindak dengan kesan reaksi persekitaran ke atas perasaan mereka semata-mata tetapi juga mengajar mereka untuk menyelami perasaan anak-anak yang masih kecil.

Menurut Herek et al. (1998) seperti kebanyakan kondisi kesihatan yang distigmakan, HIV/AIDS juga meliputi dua bentuk stigma iaitu stigma primer dan stigma sekunder. Stigma primer kebiasaannya terarah kepada pesakit apabila status seropositif diketahui umum. Manakala stigma sekunder diarahkan kepada mereka yang mempunyai hubungan langsung dengan pesakit terutamanya keluarga. Stigma dan diskriminasi terhadap HIV/AIDS berkait rapat dengan tahap pengetahuan dan persepsi umum tentang cara jangkitan virus HIV. Persepsi negatif kebiasaannya terarah kepada kumpulan berisiko seperti pengguna dadah, pekerja seks dan homoseksual yang mana tingkahlaku sosial dan seksual mereka melanggar norma budaya masyarakat setempat. Kumpulan ini diberi label dan jangkitan HIV/AIDS dipersepsikan sebagai hukuman setimpal untuk tingkahlaku mereka (Dodds, Keogh, Chime et al., 2004). Manakala reaksi dingin akibat persepsi negatif, stigma dan diskriminasi menurut Gilmore dan Somerville (1994) boleh meliputi kecenderungan untuk mengelak atau menjauhkan diri, mengganggu, mengancam atau mencederakan fizikal, memberi label sehingga berlakunya gangguan emosi, serta menafikan hak dengan menghalang pesakit atau keluarga menerima sokongan melalui tingkahlaku scapegoating. Di dalam kajian ini, masyarakat sekeliling seperti jiran tetangga didapati telah cenderung untuk menjauhkan diri atau mempamerkan reaksi takut terhadap keluarga, mengganggu emosi dengan mempunyai prasangka terhadap status pasangan dan yatim AIDS serta menghalang yatim AIDS daripada memperolehi sokongan sosial dan hak kanak-kanak ini dalam interaksi sosial. 


\section{KESIMPULAN}

Kajian ini telah mengenalpasti pengalaman keluarga mengambil alih peranan penjagaan yatim AIDS setelah kematian bapa mereka. Keluarga yang dikaji berhadapan dengan impak penjagaan apabila bertambahnya peranan kekeluargaan, kekangan kewangan, kebimbangan tentang penerimaan Yatim AIDS berhubung kematian bapa mereka serta kebimbangan kesan stigma dari reaksi masyarakat terhadap emosi serta masa hadapan Yatim AIDS.

Stigma dan diskriminasi berhubung HIV/AIDS akan terus dirasai oleh keluarga dan sukar dielak apabila pengetahuan pelbagai lapisan masyarakat tentang HIV/AIDS masih berkurangan. Apatah lagi kesan psikososial HIV/AIDS kini telah menjangkau kepada kanak-kanak tidak kira samada kanak-kanak ini turut dijangkiti HIV ataupun tidak. Penting bagi keluarga untuk tidak dibiarkan menghadapi isu stigma secara bersendirian tanpa diberikan panduan serta sokongan. Sokongan sosial untuk berhadapan dengan reaksi persekitaran perlu dititikberatkan oleh semua pihak yang terlibat dalam membantu keluarga menangani impak HIV/AIDS. Seharusnya saluran pengetahuan boleh memberi kesedaran serta menghilangkan ketakutan umum terhadap HIV/AIDS.

Penyelidikan lanjut tentang pengalaman mangsa berhadapan impak psikososial HIV/AIDS khususnya isu yatim AIDS juga boleh membantu dalam meningkatkan pengetahuan dan mengubah persepsi negatif masyarakat. Penyelidikan boleh dibuat untuk mengetahui bagaimanakah persepsi negatif dan stigma menimbulkan masalah kepada keluarga. Kajian mencadangkan agar penyelidikan dapat dibuat untuk mengenalpasti perubahan-perubahan ke atas bentuk stigma dan diskriminasi terhadap HIV/AIDS pada masa sekarang dan perbezaannya berbanding stigma dan diskriminasi yang telah wujud semasa HIV/AIDS mula dikenalpasti lebih dua dekad yang lalu. Penemuan menerusi penyelidikan diharapkan boleh mengemukakan isu-isu semasa tentang stigma HIV/AIDS yang dapat dijadikan garis panduan untuk semua pihak yang bekerja dengan pesakit atau keluarga mereka. Usaha ini penting kerana stigma dan diskriminasilah yang selama ini menyebabkan keluarga gagal memperolehi sokongan sosial. Perhatian serius bolehlah diberikan kepada aspek-aspek seperti bentuk stigma dan diskriminasi ke atas penjaga Yatim AIDS, pengaruh stigma dan diskriminasi kepada kanak-kanak Yatim AIDS serta keupayaan penjaga untuk berhadapan dengan stigma dan diskriminasi sepanjang menjaga Yatim AIDS. 


\section{RUJUKAN}

Anderson, J.R. (2001). Approach to the patient. Centers for Disease Control and Prevention : National Center for HIV, STD and TB Prevention.

Ankrah, E.M. (1994). The impact of HIV/AIDS on the family and other significant relationships : The African clan revisited. In : R. Bor \& J. Elford, The family and HIV. New York : Cassell. Hal. 23-44.

Antle, B.J., DeMatteo, D., Goldie, R.S., King, S. M., \& Wells, L.M. (2001). Challenges of parenting for families living with HIV/AIDS. Journals of Social Work. Vol 46 (2) : 159.

Bharat, S. (1999). HIV/AIDS related discrimination, stigmatisation and denial in India. Geneva: Joint United Nations Program on HIV/AIDS.

Dodds, C., Keogh, P., Chime, O., Haruperi, T., Nabulya, B., Ssanyu Sseruma, W., \& Weatherburn, P. (2004). Stigma and discrimination experienced by gay men and African people with HIV. London:Sigma Research.

Ezarina, Z. (2008). Sokongan sosial bagi keluarga pesakit HIV/AIDS: Satu kajian kes di perkampungan nelayan. Dalam Fuziah Shaffie \& Rozita Yusoff. Pembangunan komuniti marginal di Malaysia: Ke arah pengkeupayaan kendiri. UUM, Sintok:Penerbit Universiti Utara Malaysia. Hal. 237-253.

Gilmore, N., \& Somerville, M.A. (1994). Stigmatization, scapegoating and discrimination in sexually transmitted diseases, overcoming 'them' and 'us'. Social Science and Medicine, 39 : 1339 - 1358.

Herek, G.M., Mitnick, L., Burris, S., Chesney, M., Devine, P., Fullilove, T.M., et al. (1998). Workshop report on AIDS and stigma: A conceptual framework and research agenda. AIDS and Public Policy Journal, 13(1) : $36-47$.

Monasch, J. \& Boerma, T. (2004). Orphanhood and childcare patterns in Sub-Saharan Africa : An analysis of national surveys from 40 countries. AIDS 18 (suppl. 2): S55-S65.

Nugroho, F. (2012). Social services for children of mothers with HIV/AIDS. [Special Edition]. Asean Social Work Journal: 43 - 65.

Onyango, P. \& Waiji, P. (1988). The family as a resource. In: A.F. Fleming. The Global Impact of AIDS. New York : Alan R. Liss.

Subbarao K., \& Coury D. (2004). Reaching out to Africa's Orphans: A framework for public action. Geneva: The World Bank.

UNAIDS. (2011). Global report: UNAIDS report on the global AIDS epidemic.Geneva: Joint United Nations Programme on HIV/AIDS (UNAIDS). 
UNAIDS, (2010). Global report: UNAIDS report on the global AIDS epidemic.Geneva: Joint United Nations Programme on HIV/AIDS (UNAIDS).

UNAIDS, (2008). Global report: UNAIDS report on the global AIDS epidemic.Geneva: Joint United Nations Programme on HIV/AIDS (UNAIDS).

UNICEF, (2006). Africa's orphaned and vulnerable generations:Children affected by AIDS. New York: UNICEF. 


\section{Ezarina \& Haris}

